\title{
What Is the Vulnerability of a Food System to Global Environmental Change?
}

\author{
Polly J. Ericksen $^{1}$
}

\begin{abstract}
Assessing the vulnerability of broadly described food systems to global environmental change requires a new, synthetic approach. Food systems can best be conceptualized as the integration of humans and the environment or coupled social-ecological systems. However, much of the existing literature on vulnerability assessment focuses on either social or ecological systems, and conceptual gaps limit the holistic evaluation of linked systems in which both social and ecosystem outcomes are important. I suggest an approach with which to integrate factors across a food system to assess the system's vulnerability to environmental change by focusing on key processes and system characteristics. However, the multiple objectives of different actors in food systems make tradeoffs inevitable and complicate the evaluation of vulnerability. Further development and use of this approach is a promising avenue for future research because empirical evidence is needed to further elaborate these understandings.
\end{abstract}

Key Words: food security; social-ecological systems; vulnerability

\section{INTRODUCTION}

Food is central to life, and food systems are intertwined with culture, politics, societies, economies, and ecosystems. Tremendous gains in the productivity and efficiency of food systems in recent decades have reduced food insecurity and contributed to economic growth throughout the world. However, many aspects of these same systems are implicated directly and indirectly with a set of processes known as global environmental change, some of which have been shown to have negative social and environmental outcomes (Global Environmental Change and Human Security 1999, Steffen et al. 2004, Millennium Ecosystem Assessment 2005). Global environmental change in turn affects food system activities and outcomes, with potentially negative consequences for food security and future food system performance. In addition, food systems' contributions to economic growth are shadowed by increased inequity in profits and power and in food distribution at multiple scales (McMichael 2000), raising concerns even in the absence of global environmental change.

Here, I propose an approach for analyzing the vulnerability of food systems to global environmental change. This task is central to the agenda of the Earth Systems Science Partnership and the project that it sponsors: Global Environmental Change and Food Systems (GECAFS). The goal of the GECAFS research program is to understand the full range of interactions among food systems and global environmental change processes, beginning with the ways in which food systems are vulnerable to current and future environmental stressors. The approach that I describe here frames the consequences of environmental change for food systems in the context of socioeconomic and political change so as to understand the synergistic effects of the multiple stresses that interact with food systems, sometimes making these systems vulnerable. This is a complicated task because food systems encompass a range of social, institutional, and ecological components (activities, actors, and outcomes; Ericksen 2008), all of which may be vulnerable to environmental change in different ways. The current negative social and environmental consequences of food systems also raise concern that any adaptations that are implemented to lessen the vulnerability of food systems do not result in deleterious consequences for environmental outcomes, as well as social outcomes, and hence increase vulnerability in the future. Such a 
comprehensive analysis requires the integration of the concepts of vulnerability that have largely been developed separately in the social and natural sciences.

I attempt to bridge the development-oriented food security literature with the literature on vulnerability to environmental change because these communities both have much to contribute to the complex problem of food system vulnerability, but approach the issue from different perspectives. I also seek a better integration of social and ecosystem approaches to vulnerability. I suggest a systems approach (Ison et al. 1997) to move from a household-level understanding of food security dynamics to a broader, more systemic analysis that links food security outcomes to processes that drive or create vulnerability, even as these processes manifest themselves differently across spatial and temporal levels. A systems approach will also take into consideration the possible feedbacks across space and time that may also increase vulnerabilities in the future. As I argue, these feedbacks and crossscale interactions create inevitable tradeoffs within food systems, which complicate an assessment of their vulnerability to global environmental change.

This intellectual effort is important because all vulnerability assessments have policy implications (Alwang et al. 2001, Vogel and O'Brien 2004), and misguided analyses or incorrect interpretations of results contribute to flawed policy (Walker et al. 2002). Analytical clarity is essential to have any decision-making or policy impact, especially if there are inevitable tradeoffs among social and environmental outcomes. The particular policy clarification desired for food systems are: (1) to help decision makers understand that environmental change has impacts beyond those directly felt in food production; (2) to develop interventions that treat the underlying causes, rather than symptoms of vulnerability in food systems; and (3) to position researchers and decision makers to better cope with the increasing global environmental changes that are predicted to occur over the next century.

\section{CONCERN ABOUT FOOD SYSTEM VULNERABILITY TO ENVIRONMENTAL CHANGE}

Concern over the current and potentially future harmful consequences of global environmental change for food systems is motivated by four narratives, all of which are linked to policy considerations. First, in spite of advances made in the past century, chronic food insecurity persists in parts of the world. Although the causes of this food insecurity are complex, projected changes in demographics and consumption patterns have led many to worry over the ability of some populations to feed themselves in the coming 50 to 100 years, particularly in the absence of adequate policy responses (von Braun 2005). The marginality of impoverished people and their increased susceptibility to food insecurity continues in a range of rural and urban settings (Stamoulis and Zezza 2003).

Second, events of the past decade have heightened awareness of the increasing impact of natural hazards and shocks on food, income, and environmental security: examples are the tsunami of 2004, hurricane Katrina, and periodic catastrophic floods in various places. O'Brien (2006) argues that environmental shocks of this type are a major human security concern with which modern society has little capacity to cope effectively, given the widespread lack of proactive policy and preparedness.

Third, assessments such as the Millennium Ecosystem Assessment and the Global Environmental Outlook conclude with certainty that the ecosystem services enabling food production systems are being eroded through environmental trends such as changes in nutrient cycles, changes in hydrological cycles, changes in vegetation cover and composition, and pollution (Cassman et al. 2005, Wood et al. 2005). Adding to these concerns are predictions that future climate change will change the spatial and temporal distribution of crop yields as temperatures rise and precipitation patterns change over the next 100 years (Easterling et al. 2007).

Finally, and perhaps of greatest concern to food systems, is that although many improvements in human well-being depend upon social, political, and institutional improvements, these same mechanisms are inadequate to substitute for ecosystem services in many cases. Thus, the decline in wild fisheries cannot be completely reversed with aquaculture, water management is plagued by inefficiencies and overuse, and agricultural yields are stagnating in formerly intensively farmed high-productivity areas such as Punjab state in India (Cassman et al. 2005, Shah et al. 2005). These losses all have consequences for food systems and food security, 
and future trends will most likely increase these losses.

Although global environmental change encompasses changes in the biophysical environment caused naturally or caused by human activities (Global Environmental Change and Food Systems 2005), the concerns described above largely stem from evidence of the increasing influence of human activities on the biophysical environment. This strong human influence places the concern about the vulnerability of food systems in a broader context of concern about the tensions or tradeoffs between ensuring or improving human well-being and maintaining ecosystem services.

\section{DEFINITION OF A FOOD SYSTEM}

Food systems comprise a set of activities and outcomes ranging from production through to consumption, which involve both human and environmental dimensions (Appendix 1). The primary policy objective of these systems is food security, which is defined as "all people, at all times, have physical and economic access to sufficient, safe and nutritious food to meet their dietary needs and food preferences for an active and healthy life" (FAO 1996). This is not meant to imply that all food systems actually result in food security; these outcomes can be better or worse in differently structured food systems as a result of shocks and stresses or because of decisions made by individuals and households. Food security and food systems are highly contested issues in which social and political values and concerns play a significant role, particularly in the evaluation of whether or not food systems result in food security as defined above (Ericksen 2008). When a food system fails to deliver food security or has the potential to do so in the face of future stress, whether the stress is an economic shock, institutional failure, actors in conflict, or environmental change, the system can be considered to be vulnerable to one or more of the stresses. In addition to food security, food systems produce outcomes that contribute to or detract from ecosystems and the services they provide, income for many people ranging from agricultural workers to retailers, and a host of other environmental and social welfare outcomes important to society. Given that global environmental change is affected by food system feedbacks to the ecosystem, failure to deliver these other outcomes can also be taken as an indication of food system vulnerability. Finally, food systems operate across levels of management and analysis. Cross-scale interactions, a topic of concern to many researchers, are critical to their function.

I use the term "system" to be comprehensive and inclusive and to describe interactions and processes as linked, but by no means perfectly controllable or predictable. Research in both the natural and social sciences uses the idea of a system to explain complex dynamics, although as Füssel and Klein (2006) point out, the approach and foci differ. One can combine the natural science concern with explaining the dynamics and behavior of a complex system with the social science focus that is more concerned with explaining the behavior of actors and the role of information, power, and institutions (Füssel and Klein 2006).

\section{CONCEPTUAL UNDERSTANDINGS OF VULNERABILITY FROM SOCIAL AND ECOSYSTEM SCIENCES}

Before the current interest in vulnerability to global environmental change, agricultural economists and food security analysts developed empirically based theories explaining food security. There is consensus that households may become food insecure through one or more failures in three types of entitlements: availability, including the need for a stable supply of food; access; and utilization (Maxwell 2001). Availability includes not only the production of food, but also distribution and exchange networks. Access comprises affordability, how well markets function, and whether or not preferences are met. Utilization includes the nutritional and social values of food, along with food safety (Appendix 1). The food security lens, adopted in slightly varied form by most donor and United Nations agencies, institutionalizes the consensus about the multiple aspects of food security. This helps analysts have clearer understanding of the causes and manifestations of food security, emphasizing in particular the social and economic dimensions (Stephen and Downing 2001). A good deal of research effort has been aimed at moving beyond environmental determinist explanations of food security. Thus, although environmental stresses contribute to food insecurity, they do so always in combination with other drivers such as poverty, conflict, and land tenure constraints (Devereux 2000, Devereux and Edwards 2004, Misselhorn 2005). Equally important is the 
understanding that food security is only one of many risks that households manage through their livelihood strategies (e.g., Ellis 2000). Livelihood strategies are therefore very important for household food security status.

The burgeoning literature on vulnerability to global environmental change is driven by a concern for understanding what potentially unprecedented ecological and climatic change might do to human well-being and the integrity and functioning of ecosystems. It seeks to examine the dynamics of impacts, as well as causality, for a range of units of analysis at various scales.

Social vulnerability to climate change and other types of global environmental change is loosely defined as an inability to cope with external pressures or change, leading to the potential for an adverse outcome (O'Brien et al. 2004a, Adger 2006). Any unit of analysis, from a local to a regional or global system, can be socially vulnerable, although the processes that drive vulnerability and the manifestations of vulnerability will vary with the level of analysis and context. Thus, social vulnerability will always be highly differentiated.

The most popular generic framework, from the Third Intergovernmental Panel on Climate Change Assessment Report (McCarthy et al. 2001), suggests that vulnerability is a function of exposure, sensitivity, and coping or adaptive capacity. Exposure means that a unit must be exposed to a shock, threat, or stress to be vulnerable to it. Identifying exposure as a separate component implies that the potential for harm is only one part of vulnerability. An important conceptual advance is that of double exposure, or the idea that synergies among multiple dynamic processes of change combine to cause vulnerability. An environmental shock or stress may be the trigger that sends people into a vulnerable state, but other shocks such as a change in agricultural policy coincide with or contribute to this underlying vulnerability (Leichenko and O'Brien 2002, O'Brien et al. 2004b).

Sensitivity follows exposure. Although everyone in a place may be exposed to a stress, for example little rain, they are not equally likely to experience its impacts because some are more sensitive than others. Farmers growing rain-fed maize will be more sensitive to a drought than those who grow sorghum because of differences in the crops' sensitivity to water stress. Sensitivity depends upon inherent characteristics of both the system and the shock to which it is exposed (Ford et al. 2006, Eakin et al. 2007).

Coping capacity expresses the understanding that people need more than just access to resources to be less vulnerable, but also active strategies to manage resources in the face of risk (Barrett and Carter 2000). Coping capacity is probably most meaningful if used to represent short-term responses such as selling a cow or reducing the number of meals to ensure survival in the near future, which may involve costs such as a reduction in assets. The notion of adaptive capacity implies longer term changes in behavior and livelihood strategies to ensure the maintenance of income or food security for the foreseeable future in the face of changes that are yet to come (Berkes and Jolly 2001). It implies the ability to take active steps to reorganize for better management (Eakin 2005). The line between coping and adaptive capacity is not always clear; however, coping capacity is best understood in relation to managing current stresses and is often reactive, whereas adaptive capacity should refer to the potential to adapt to future uncertain changes without increasing vulnerability and is proactive.

A major determinant of both coping and adaptive capacity is access to assets or entitlements (Adger and Kelly 1999), which stems from the basic entitlement theory that Sen (1981) used to explain food insecurity as a function of more than just availability. Assets range from physical to social and political. Generally, people with greater endowments of resources and the entitlements to use them fare better in the face of stresses and shocks. However, there is increasing recognition that the institutional and policy context is also critically important because it frames people's ability to take action (Bohle 2001, Ellis and Freeman 2004, Eakin et al. 2007). In addition, vulnerability is always caused by multiple stressors and is the product of complex interactions within the system, as well as those with a given disturbance such as environmental change. Hence, adaptive capacity may also be constrained by the need to manage other stressors.

Adger (2006) summarizes the generic features of social vulnerability for any system, stating that the social vulnerability of a system is a function of the resources a system has to use, the distribution of those resources around the system, and the capacity 
of the institutions mediating interactions within the system. Ultimately, however, the focus of social vulnerability approaches is the heterogeneous social outcomes, rather than the ecosystem outcomes.

Turning to ecosystem studies, the simplest notion of ecosystem vulnerability implies that an ecosystem cannot withstand shocks or stresses without losing its basic ecological properties and shifting to a different state. Often, human activities are assumed to drive this vulnerability. For example, Gritti et al. (2002) classify Mediterranean ecosystems as vulnerable if the invasion by exotic species changes the overall species composition so much that the ecosystem has fundamentally different properties. Other authors define ecosystem vulnerability in terms of the loss of ecosystem services (Millennium Ecosystem Assessment 2003, Christensen et al. 2004). Ecosystem services are those that people rely on for food production and health, as well as those services that ecosystems require to sustain themselves. Studies such those by Schroter et al. (1999) and Asner et al. (2005) have documented the relationships between stressors and ecosystem responses. The assumed tension between ecosystem services and human activities and wellbeing is important for food systems analysis and is at the heart of the major global environmental assessments such as the Millennium Ecosystem Assessment and the Global Environmental Outlook.

Holling's (1986) theory of adaptive cycles provides an approach that relies on the concept of resilience instead of vulnerability, although it is rooted in the same ecological theory and is also focused on the influence of human management and activities. Resilience is defined as the capacity to absorb change without shifting to an altered state with different properties. Resilience is usually lost because managers try to control naturally occurring fluctuations, rather than allow them to persist, or because they allow foreign material to enter the system (Gunderson 2003). The new states, e.g., shrub-dominated pasture, dead coral, or turbid lake water, are themselves very resilient, and it is almost always expensive and difficult to get ecosystems to switch back to a previous state (Carpenter et al. 2001).

The idea of coupled social-ecological systems (SESs) explicitly accommodates the social mechanisms behind ecosystem management (Berkes and Folke 1998). The concept of coupled systems presents ecological and social processes as co-evolving and joined, not distinct and separate. A resilient SES has plenty of buffering capacity and can absorb disturbances. Usually, slowly changing variables are responsible for this, especially over the long term. Diversity is a key factor for buffering capacity. A resilient system can also take action, including restructuring or reorganizing, to respond to feedbacks, which in an SES depends on how well social managers understand these feedbacks. Finally, a resilient system can learn, which means that past mistakes are incorporated into new responses and better management (Carpenter et al. 2001, Holling 2001, Deutsch et al. 2003).

The focus on management options and ecosystem services suggests that a resilience approach would be useful for food systems because they are highly managed. The approach maintains that adaptive management is critical to maintaining system resilience and avoiding a flip to an undesirable state. Adaptive management accepts change and fluctuations as the norm and furthermore as important for maintaining system resilience (Gunderson 2003). This theory places a high premium on learning about systems over time and adapting management as new phenomena emerge. Although this theory is helpful in conceptualizing the interactions between ecological and social systems, it ultimately is concerned more with ecological than social outcomes, except insofar as the ecosystem services upon which human wellbeing directly depends are affected, for example, certain natural resource-based livelihood strategies (Berkes and Jolly 2001, Alcorn et al. 2003).

The studies of Adger (2006), Folke (2006), Nelson et al. (2007), and Young et al. (2006) all represent recent efforts to bridge the conceptual differences between ecosystem and social approaches to vulnerability studies. Central to this reconciliation is the acceptance of the idea of a coupled SES. Both the social and ecological approaches to vulnerability emphasize the heterogeneous or differentiated distribution of outcomes across time and space. They also both emphasize the importance of adaptive capacity in reducing vulnerability. However, no approach is yet entirely suitable to holistically evaluate food system vulnerability. Social vulnerability approaches apply to parts of a food system, primarily either the actors or the social welfare and food security outcomes. They are generally less system-focused than ecological approaches, so it is difficult to trace connections among activities, actors, and outcomes, particularly 
feedbacks. Ecological literature is comfortable with systems and feedbacks, but is weak on the social drivers and outcomes relative to those for ecosystems. It also assumes that these are directly linked and that improvements in ecosystem services also improve human well-being. Furthermore, the ecological literature is less clear about the desirability of resilient states than the social literature, in which vulnerability is always viewed as a negative state.

A challenge for both fields is to identify the pathways leading to vulnerability. In modern food systems, these are complex because interactions cross spatial and temporal scales and the links between the social and ecological components are often indirect. A shock may not be felt directly, and conflicts may arise among the outcomes, complicating the evaluation of food system vulnerability because one outcome may increase at the expense of another. Another challenge that food systems present is that they are a unique form of coupled SES in that they depend upon ecological variables for their most basic function, yet they are largely driven by social processes and policies; this forces the tensions between human-well being and ecosystem services to the forefront of food system assessment.

\section{VULNERABILITY OF FOOD SYSTEMS}

A generic diagram to depict the environmental and social dimensions of food system vulnerability is shown in Fig. 1. This explains vulnerability to environmental change as a function of exposure to an environmental hazard, which is mediated by social factors and institutions, which combine to determine the adaptive capacity and hence the overall vulnerability of the food system (Ingram and Brklacich 2002). Although this explains generally how to frame vulnerability, a more detailed approach is needed to explain the mechanisms and pathways by which a food system becomes vulnerable and the implications of vulnerability for a food system.

There is scattered evidence regarding the vulnerability of food systems. Although there is a rich body of information on food security outcomes, much of this is based on household studies similar to social vulnerability approaches; see for example, Ziervogel et al. (2006) and Devereux and Edwards (2004) for explicit discussions of climate change and household food security. Although these studies illustrate the strength of household food security analysis in that they emphasize both external drivers such as policies and markets, as well as internal responses by households in the context of their livelihood strategies, a food systems approach requires a focus on food system structure, rather than household and national policy structures. Downing (2002) attempts to link indicators of vulnerability to broader system indicators; he does not really use the notion of a coupled socialecological system (SES) that the literature reviewed here suggests is important for food systems. On the ecosystem science side, there are few studies that refer to the activities in a food system and how they could be vulnerable to environmental change in the context of multiple stressors. The exception is food production in agricultural and aquaculture systems, and most of this literature looks only at one or two stressors and focuses on crop yields (Reilly and Schimmelpfennig 1999, Fischer et al. 2002, 2005). Even the analysis of the Millennium Ecosystem Assessment (Cassman et al. 2005, Wood et al. 2005) limits most of its discussion to food production systems and has little discussion about the access and use dimensions of a food system. A primary concern for food security outcomes is an analysis that goes beyond food production systems.

Fraser (2003, 2006, Fraser et al. 2005) borrows from both social and ecological theories to analyze food system vulnerability. He looks at both the structure of food system activities and the resultant pattern of food insecure outcomes for several historical cases. His research highlights key differences between the concepts of ecological vulnerability and social vulnerability when applied to food systems. Social vulnerability as understood by entitlement theory is most commonly associated with low wealth and economic or social isolation or weak connections. This is the opposite for ecological systems as explained by resilience theory; when they are high in wealth and connections, they may be most vulnerable to collapse. The feature common to both is the importance of maintaining diversity to preserve options in a crisis.

Young et al. (2006) discuss the implications of globalization for coupled SESs, drawing upon literature on the institutional dimensions of environmental change, as well as the social and ecological vulnerability literature summarized here. Their analysis is highly relevant to food systems. Key to their understanding of vulnerability is that 
Fig. 1. Food system vulnerability as a function of the environmental change hazard, exposure, and adaptive capacity. Source: Ingram and Brklacich (2002).

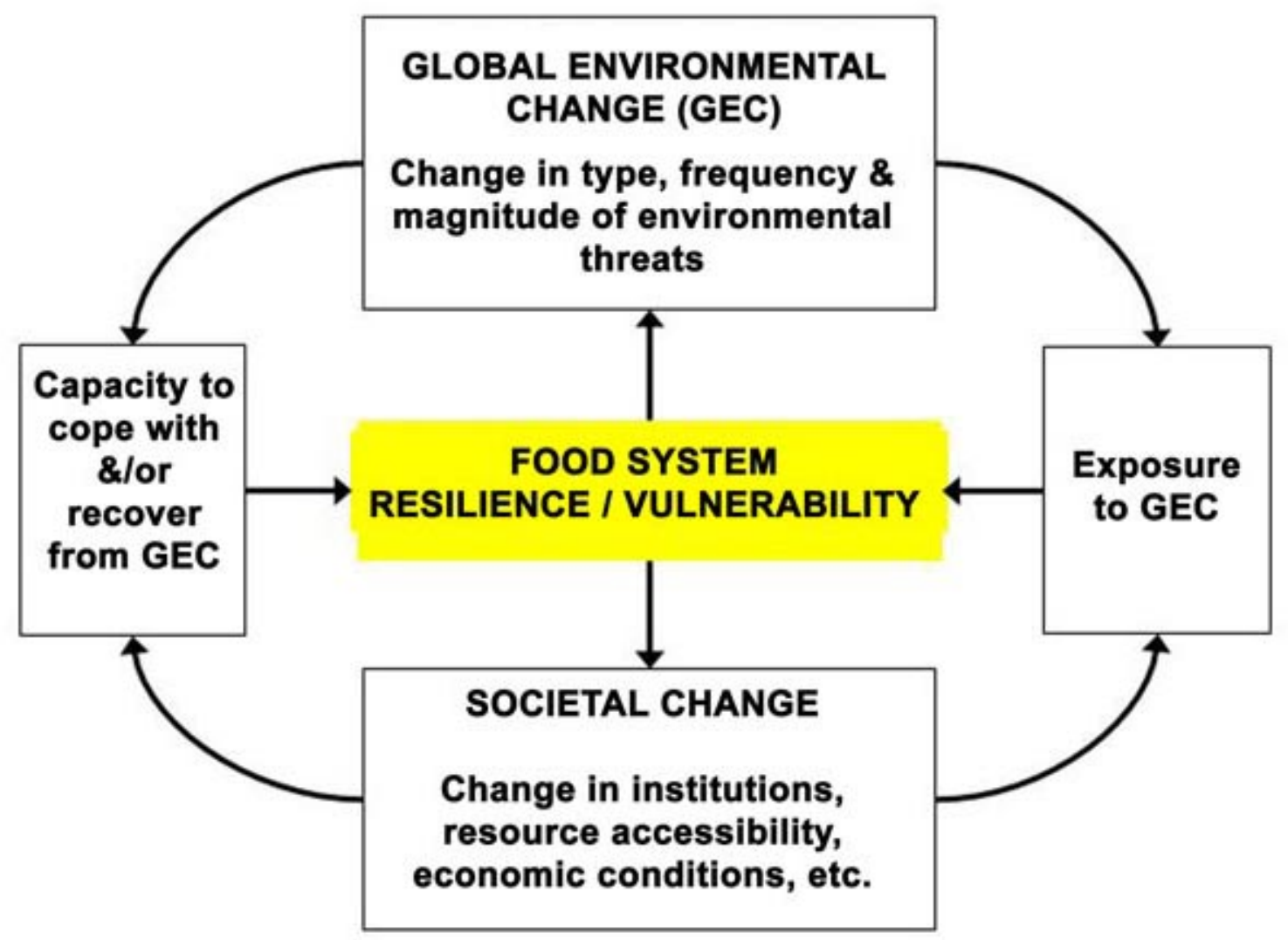

adaptation to avoid it requires structural change within or by a system so that the system does not lose any of its key functions. This suggests that an important analytical step is to define these key functions initially to understand what vulnerability means for a given system. Young et al. (2006) conclude that in many SESs today, social complexity has come to replace biophysical complexity as humans have inserted themselves more and more into these systems. They highlight four important impacts of globalization for SESs: it has increased the connections among disparate systems; it has increased the speed with which disturbances and change flow through and between systems; it has changed the traditional scalar relationships so that there are now too many crossscale interactions; and it has significantly decreased the diversity in SESs. These changes raise serious questions about the ability of systems to undergo the structural changes necessary to adapt to disturbances, rather than moving into a vulnerable or less desirable state.

The impacts of globalization are also a concern for political-economic and sociological critiques of food systems such as those of McMichael (2000) and Hendrickson and Heffernan (2002). These authors suggest that although very powerful corporations govern modern food systems, which are characterized by industrial agricultural production, factory-based processing, and supermarketcontrolled retail, the systems themselves may be generally vulnerable to shocks. This vulnerability arises from the degree of specialization and homogenization, which can make it difficult to adjust to changes in preferences or to serve smaller markets. McMichael (2007) also suggests that the level of subsidization that affluent diets require in 
terms of energy and global markets threatens their sustainability.

Sundkvist et al. (2005) maintain that the negative social and environmental consequences of food production result from the current food system marketing structure in Western countries. This structure distances consumers from producers and thus inhibits the recognition of and response to feedbacks in the food supply chain. They identify four main trends responsible for this vulnerability: intensification, specialization, distancing, and concentration and homogenization. Feedbacks within the food system can either be masked, i.e., not perceived, or disregarded, i.e., perceived but not acted upon in response. Often this is because the production takes place at a different point in space or time from consumption, but it also occurs because consumer knowledge of food systems has declined and there are insufficient institutional mechanisms within most food systems to manage feedbacks. The solutions that Sundkvist et al. (2005) propose are to encourage more localized food production, to decrease the distance between producers and consumers, and to improve institutional management to tighten the feedback loops.

The lessons to be drawn from these analyses are the following:

1. System structure is important and is best understood as a function of historical and current interacting processes;

2. There is a need for outcome-oriented evaluation criteria to focus on food security, which is a particular development issue;

3. Adaptive capacity is critical to both social and ecological understandings of vulnerability. This highlights human agency and the role of interventions;

4. As people use resources to meet multiple objectives, they face tradeoffs in all decisions and furthermore will usually not adapt directly to an environmental stressor, particularly in food systems;

5. It is important to be explicit about the level and scale of analysis (sensu Cash et al. 2006);

6. It is not sufficient to address each food system activity or outcome separately because the vulnerability of a system arises from the sequencing of certain processes and activities and the interactions among them (Turner et al. 2003).

\section{TOWARD AN APPROACH FOR ASSESSING FOOD SYSTEM VULNERABILITY}

I now outline the components of an approach for understanding how food systems are or might be vulnerable to global environmental change. Eakin and Luers (2006) suggest a series of questions to help resolve the confusion and complexity that arise when trying to integrate social and ecological approaches to assessing vulnerability. I have adapted these for food systems as a way of organizing the necessary tasks for evaluating vulnerability across a food system (Table 1$)$. The first step is to clarify the principal functions of a food system, the parts of the food system that might be vulnerable to global environmental change stressors, and perhaps most importantly, what the evaluation criteria for this will be. In the case of food systems, I propose that any of the outcomes can indicate this vulnerability, although food security outcomes are presumed to be the most significant indications of overall system vulnerability because food security is the principal normative objective of food systems. However, these outcomes will be evaluated differently by different stakeholders and at different levels. This is an inevitable consequence of the way food systems are organized.

The second step is to understand how an environmental change stress might be transmitted through a food system because food system complexity means that impacts may not always be felt directly. The third step is to define and explain sources of adaptive capacity in the system. Eakin and Luers (2006) additionally recommend the identification of thresholds of change and indicators, which is also a challenge for broadly defined food systems because they integrate so many components, some of which overlap and may compete. Fast and slow variables are very important for resilience and are a concern for food systems because a change in these dynamics is one of the biggest impacts from globalization. A critical issue for food systems is that improvements in one outcome may be at the cost of another, although 
Table 1. Questions to help assess the vulnerability of food systems to global environmental change.

\begin{tabular}{ll}
\hline \hline Vulnerability focus & Food system concern \\
\hline $\begin{array}{l}\text { What are the key functions of the } \\
\text { system? }\end{array}$ & $\begin{array}{l}\text { Four major activities: production, } \\
\text { processing, distribution, and } \\
\text { consumption }\end{array}$ \\
& $\begin{array}{l}\text { Three categories of outcomes: food } \\
\text { security, social welfare, and } \\
\text { environment }\end{array}$
\end{tabular}

What is potentially vulnerable?

Consumers can be food insecure

The environment can be degraded

The social welfare of both consumers and agents in the food chain can be diminished

Food system activities can be disrupted

How is a global environmental change shock or signal transmitted?

What gives the system adaptive capacity?

Can thresholds of vulnerability be defined?

Which processes are fast? Which are slow?

Who are the winners and losers?
Shocks can be transmitted over long or short distances and via few or many processes, which may magnify or diminish their impact. They can be ignored or masked. Cross-scale interactions may be particularly outcomes

Specific social, economic, institutional, and ecological components of the system, i.e., the actors and their resources, as well as their relationship to one another within the system

Food security outcomes are often measured against standardized criteria. The same is attempted for many ecosystem criteria

Fast disturbances attract attention, but the slowly changing variables are more important

Not all food system components will necessarily improve together dangerous because they can complicate

\section{Evaluation criteria}

The three outcome categories should illustrate whether food system activities are functioning properly

The outcomes are prioritized by social values or policy goals, and the prioritization is scale dependent

Food insecurity arises because of a loss of availability, a loss of access, or a lack of proper use

Biodiversity loss, nutrient cycle alteration, water pollution, etc.

Income loss, increased inequity, increased migration, etc.

The food system outcomes should, but may not, indicate this because of masking or substitutions among activities

An increase or decrease in system vulnerability as a result of the shock. One or more outcomes may indicate this vulnerability. Possibly no outcomes will indicate any vulnerability.

Adaptive capacity is the major projection against vulnerability

A defined limit is important to motivate policy responses

Resilience usually comes from slowly changing variables, but rapid changes can trigger temporary vulnerability. This is scale dependent

This will depend upon social and political priorities

Note: Adapted from Eakin and Luers (2006). 
understanding when, where, and how often this occurs requires empirical investigation. The most obvious example of this is the intensive production of monoculture crops at the expense of diversity. Managing these tradeoffs will be a challenge for adaptation strategies and policy.

Much of the vulnerability and systems literature suggests that processes are critical to understanding the underlying causes of vulnerability; thus, researchers propose long-term solutions for adaptation to ongoing environmental change and suggest moving beyond outcome-based indicators (O'Brien et al. 2004a). I propose a preliminary list of food system characteristics that are part of processes that could make a food system vulnerable in the face of a shock or stress, based on the literature reviewed here (Table 2). This can serve as a checklist for analyzing food systems to identify warning signs of vulnerability, although the outcomes of interest will have to be evaluated as well. However, as for the evaluation of the vulnerability of a food system (Table 1), the outcomes may not be observed or may be ignored; thus, it is also important to look for these underlying processes as indicators of a problem.

I am currently working with a team of researchers on five case studies of district-level food systems across the Indo-Gangetic Plain. We use a simple matrix approach to assess the sensitivity, adaptive capacity, and vulnerability of food systems, using food security determinants as the specific units of analysis. Adaptive capacity is used to highlight a concern with the ongoing ability to buffer against future change. I present an example using preliminary field data gathered for food systems in the western Indo-Gangetic Plain (Table 3).

The environmental change stressor is declining water availability. In this example, the food system outcome of concern is food utilization, and the first component being analyzed is nutritional value. The specific characteristics of each determinant are outcomes of the food system for that site. For example, the primary protein is lentils. The sensitivity of lentils to decreased water availability during a drought (the hazard) is a function of the hazard timing and duration, as well as the production process and requirements for lentils. However, lentils can remain in the diet during a drought because the strong regional market for lentils means that they are readily available from other areas that are less affected by drought. Thus, the market provides the food system with adaptive capacity, which in turn reduces the vulnerability of the primary protein in this diet to drought. However, food diversity suffers because the local production of milk is more sensitive to drought, and milk is not available from elsewhere because of weak markets.

In the case of affordability, indicated by household income, vulnerability depends on the ability to migrate to find off-farm sources of income. Allocation, indicated by the price of the main staple food, wheat, is not vulnerable to declining water availability. Finally, the availability of food from local production is moderately vulnerable, depending on whether or not households can afford to install groundwater tubewells for irrigation. In all cases, a mix of both local- and regional-level factors contributes to food system vulnerability, as expressed for households across a district. Both indicators (e.g., of food security status) and processes are used in this analysis.

Taken together, the processes described in Tables 1-3 suggest an initial approach for identifying food system vulnerability syndromes (or constellations of processes with identifiable patterns; PetschelHeld et al. 1999) to establish a database that might serve for a meta-analysis of food system vulnerability. If three sets of key characteristics can be systematically identified for a sufficient number of food systems in specific geographic locations around the world, it should be possible to start to identify the symptoms of food system vulnerability syndromes and the key interactions that cause these syndromes. These sets of characteristics are: how a global environmental change shock or signal is transmitted through the food system, including the sequencing of events and the scale of interactions; how the food system is sensitive to the global environmental change shock; and the adaptive capacity of the food system. This could lead to subsequent work to identify thresholds of change and to model the interactions among stressors, attributes, and outcomes, as suggested by Eakin and Luers (2006), to improve the general understanding of food system vulnerability.

Because food systems incorporate disparate components and objectives, the approach for analyzing their vulnerability will have to allow for multiple expressions with different conceptions of vulnerability. It is still not clear whether the vulnerability of one activity or one outcome means that the whole system for a given location is 
Table 2. Characteristics of food systems that may indicate vulnerability.

\begin{tabular}{ll}
\hline \hline Food system characteristic & Potential links to vulnerability in the food system \\
\hline Heavy reliance on external or distant resources & $\begin{array}{l}\text { Hard for consumers to react to production problems; more potential for } \\
\text { weak links in the commodity chain }\end{array}$ \\
Low diversity in assets or entitlements & $\begin{array}{l}\text { Consumers have few options if regular food security entitlements fail; } \\
\text { agricultural production is more susceptible to degradation or } \\
\text { disturbance; the diversity of assets upon which to draw is critical to } \\
\text { social adaptive capacity and ecological resilience }\end{array}$
\end{tabular}

Inequity in either access to resources and/or the ability to take action to use or increase them

Institutional weaknesses and low institutional capacity

Inflexible policy

Lack of functioning markets and low levels of economic activity

Highly specialized production, supply, and marketing chains

Ignoring slow variables and only responding to fast triggers
Inequity is a sign of social vulnerability

Institutional capacity is critical to management for both social and environmental outcomes; weak institutions result in poor management

Adaptation in complex systems requires flexible management

Markets play a key role in food systems and ensure that demand meets supply; low levels of economic activity constrain access to food

Highly specialized chains have low diversity, which is a key component for buffering against shocks such as production failures

Ecological resilience depends on slow variables

Cross-scale interactions, including subsidies, that Surprises usually lead to crises; uncertainty can paralyze decisions are poorly understood and lead to uncertainty and surprise

Insufficient recovery from previous shocks that have reduced the adaptive capacity

When the adaptive capacity is eroded, vulnerability is increased and resilience is lost when a shock or surprise overwhelms the system

vulnerable because there are two few studies from which to draw conclusions. Empirical work is needed to establish patterns for a number of food systems. The example that I provided (Table 3 ) does not address intrasystem tradeoffs, although it is possible that gains in protein availability from lentils could come at the expense of milk availability if farmers reorganize their production systems in response to the threat of drought and markets cannot guarantee the allocation of milk products. It is likely that component vulnerabilities will be unevenly distributed over space and time, and there is a real possibility that these vulnerabilities will contradict one another. The examples in Table 3 could occur for the same food system: one component, e.g., primary protein, is resilient in a drought, yet the other, e.g., dietary diversity, is vulnerable. Another characteristic of food systems is geographic heterogeneity, which means that one area may be food secure at the expense of another. A concern with equity means that food systems are vulnerable as long as tradeoffs exist between outcomes (Table 2).

Thinking even more broadly, market-oriented, small-scale agriculture is economically risky for farmers and many are opting out of it, yet local and diversified sources of production may offer a more environmentally sustainable type of agricultural system. Conversely, if farmers integrate into the international trade economy and produce crops for export, thereby earning income to purchase food and have a broader array of food entitlements, it is unclear what the implications for food provisioning will be over the long run as local sources become less important. It is not yet possible to decide 
Table 3. Example of the components of food system vulnerability to decreased water availability.

\begin{tabular}{|c|c|c|c|c|}
\hline Key determinant & Determinant characteristics & $\begin{array}{c}\text { Sensitivity to water } \\
\text { availability }\end{array}$ & Adaptive capacity & $\begin{array}{l}\text { Vulnerability to } \\
\text { water availability }\end{array}$ \\
\hline
\end{tabular}

NUTRITIONAL VALUE

Food diversity Milk supplements a diet Cows need 4 months of of rice and lentils rain to produce milk

Primary protein Lentils are eaten every Lentils need 2 months of day rain

\section{AFFORDABILITY}

Household income Agriculture is the main source of income

Government policy The wheat price is for staple foods controlled by the national government

PRODUCTION

Irrigation availa- Irrigation is fed by bility surface water
Agricultural earnings depend on good yields and functioning markets

When crops fail, some work can be found in towns or farther away

None Not applicable Low: not sensitive

No functioning milk market to purchase from when own production fails

High: no ability to purchase milk

The lentil market functions Low: lentils can be so that lentils can always purchased be bought

Moderate: social and economic constraints on migration

Irrigation quantity declines Tubewell irrigation is costly to install
Moderate: approximately half of households have a tubewell

Note: The example is loosely based on unpublished data from the Global Environmental Change and Food Systems Indo-Gangetic Plain regional project.

whether food systems are more or less vulnerable to global environmental change if food is produced locally than if consumers rely on international trade. This demonstrates why an approach that links processes to outcomes and evaluation criteria is needed.

The answers to these sorts of questions and the ability to define thresholds of vulnerability require tools and data that go beyond the concepts discussed here, for example, scenario exercises and a framework for evaluating adaptation options. The approach that I outline here, however, provides a basis for identifying vulnerability across broadly described food systems.

\section{CONCLUSIONS}

Assessing the vulnerability of modern food systems to the increasing trends of global environmental change, much of which is human influenced or caused, is a not a straightforward task. There is as yet insufficient understanding of what vulnerability in this particular type of social-ecological system constitutes. I have tried to highlight the important key social dimensions: access to entitlements and the policy and institutional environment. The key ecosystem dimensions are diversity and adaptive managers with appropriate information and flexibility. 
I suggest that vulnerability will be rooted in the processes involved in food systems, which are a product of activities and responses to external and internal drivers and changes. This analytical approach should help in understanding how vulnerability is expressed in a food system, where the potential for vulnerability lies, and how vulnerability will arise or be mitigated by adaptive capacity. However, empirical research and case studies are needed to demonstrate whether this approach is useful for food system management.

I also raise a new research issue. There are still questions about conceptual clarity, the interpretation of signals, and the resolution of tradeoffs across scales that need to be answered before food systems and their vulnerability to global environmental change can be fully understood. These tradeoffs will be resolved differently depending on the socially determined evaluation criteria. To have a policy impact, this approach will benefit from empirical research contributions aimed at helping decision makers adapt food systems and enhance food security in a rapidly changing world.

Responses to this article can be read online at:

http://www.ecologyandsociety.org/voll3/iss2/art14/responses/

\section{Acknowledgments:}

I thank Hallie Eakin, John Ingram, Barbara Huddleston, and several anonymous reviewers for their helpful insight and comments. This paper is a contribution to Global Environmental Change and Food Systems (GECAFS; www.gecafs.org), a joint project of the Earth Science System Partnership (ESSP). I am grateful for financial support from the UK Economic and Social Research Council (ESRC) and National Environmental Research Council (NERC).

\section{LITERATURE CITED}

Adger, W. N. 2006. Vulnerability. Global Environmental Change 16(3):268-281.

Adger, W. N., and P. M. Kelly. 1999. Social vulnerability to climate change and the architecture of entitlements. Mitigation and Adaptation Strategies for Global Change 4(3-4):253-266.
Alcorn, J. B., J. Bamba, S. Masiun, I. Natalia, and A. G. Royo. 2003. Keeping ecological resilience afloat in cross-scale turbulence: an indigenous social movement navigates change in Indonesia. Pages 299-327 in F. Berkes, J. Colding, and C. Folke, editors. Navigating social-ecological systems: building resilience for complexity and change. Cambridge University Press, Cambridge, UK.

Alwang, J., P. B. Siegel, and S. L. Jorgensen. 2001. Vulnerability: a view from different disciplines. Social Protection Discussion Paper Series Number SP 0115. World Bank, Washington, D.C., USA. Available online at: http://www-wds.worldbank.org/ external/default/main?pagePK=64193027\&piPK $=6$ $4187937 \&$ theSitePK $=523679 \&$ menuPK $=641875$ $10 \&$ searchMenuPK $=64187283 \&$ theSite $\mathrm{PK}=52367$ 9\&entityID $=00009494601120804004787 \&$ searc hMenuPK=64187283\& theSitePK=523679.

Asner, G. P., R. S. deFries, and R. Houghton. 2005. Typological responses of ecosystems to land use change. Pages 337-344 in R. S. DeFries, G. P. Asner, and R. Houghton, editors. Ecosystems and land use change. American Geophysical Union, Washington, D.C.

Barrett, C. B., and M. R. Carter. 2000. Can't get ahead for falling behind: new directions for development policy to escape poverty and relief traps. BASIS Brief Number 2, Madison, Wisconsin, USA. Available online at: http://www.ies.wisc.edu/ ltc/bas-puba.html\#brief.

Berkes, F., and C. Folke. 1998. Linking social and ecological systems for resilience and sustainability. Pages 1-25 in F. Berkes and C. Folke, editors. Linking social and ecological systems: management practices and social mechanisms for building resilience. Cambridge University Press, Cambridge, UK.

Berkes, F., and D. Jolly. 2001. Adapting to climate change: social-ecological resilience in a Canadian western Arctic community. Conservation Ecology 5(2): 18. [online] URL: http://www.consecol.org/vol5/ iss $2 / \operatorname{art} 18 /$.

Bohle, H.-G. 2001. Vulnerability and criticality. IHDP Update: Newsletter of the International Human Dimensions Programme on Global Environmental Change Number 2. Vulnerability article 1. International Human Dimensions Programme, Bonn, Germany. [online] URL: http:// 
www.ihdp.uni-bonn.de/html/publications/update/ IHDPUpdate01 02.html.

Carpenter, S., B. Walker, J. M. Anderies, and N. Abel. 2001. From metaphor to measurement: resilience of what to what? Ecosystems 4 (8):765-781.

Cash, D. W., W. N. Adger, F. Berkes, P. Garden, L. Lebel, P. Olsson, L. Pritchard, and O. Young. 2006. Scale and cross-scale dynamics: governance and information in a multilevel world. Ecology and Society 11(2): 8. [online] URL: http://www.ecology andsociety.org/vol11/iss2/art8/.

Cassman, K. G., S. Wood, P. S. Choo, H. D. Cooper, C. Devendra, J. Dixon, J. Gaskell, S. Khan, R. Lal, L. Lipper, J. Pretty, J. Primavera, N. Ramankutty, E. Viglizzo, and K. Wiebe. 2005. Cultivated systems. Pages 745-794 in Millennium Ecosystem Assessment. Ecosystems and human well-being: current state and trends. Island Press, Washington, D.C., USA. Available online at: http:/ /www.millenniumassessment.org/en/Condition.aspx

Christensen, L., M. B. Coughenour, J. E. Ellis, and Z. Z. Chen. 2004. Vulnerability of the Asian typical steppe to grazing and climate change. Climatic Change 61(3):351-368.

Deutsch, L., C. Folke, and K. Skånberg. 2003. The critical natural capital of ecosystem performance as insurance for human well-being. Ecological Economics 44(2-3):205-217.

Devereux, S. 2000. Famine in the twentieth century. IDS Working Paper 105. Institute of Development Studies, University of Sussex, Brighton, UK. Available online at: http://www.ntd.co.uk/idsbookshop/ details.asp?id=541.

Devereux, S., and J. Edwards. 2004. Climate change and food security. IDS Bulletin 35(3):22-30.

Downing, T. E. 2002. Linking sustainable livelihoods and global climate change in vulnerable food systems. die Erde 133(2002)363-378. Available online at: www.vulnerabilitynet.org/OPMS/ getfile.php?bn=seiproject hotel\&key $=1140130078$ \&att $\mathrm{id}=808$.

Eakin, H. 2005. Institutional change, climate risk, and rural vulnerability: case studies from central Mexico. World Development 33(11):1923-1938.
Eakin, H., and A. L. Luers. 2006. Assessing the vulnerability of social-environmental systems. Annual Review of Environment and Resources 31:365-394.

Eakin, H., M. Webhe, C. Ávila, G. Sánchez Torres, and L. A. Bojórquez-Tapia. 2007. Social vulnerability of farmers in Mexico and Argentina. Pages 257-278 in N. Leary, C. Conde, J. Kulkarni, A. Nyong, and J. Pulnin, editors. Climate change and vulnerability. Earthscan, London, UK.

Easterling, W. E., P. K. Aggarwal, P. Batima, K. M. Brander, L. Erda, S. M. Howden, J. M. A. Kirlenko, J. Morton, J.-F. Soussana, S. Schmidhuber, and F. N. Tubiello. 2007. Food, fibre and forest products. Pages 273-313 in M. L. Parry, O. F. Canziani, J. P. Palutikof, P. J. van der Linden, and C. E. Hanson, editors. Climate change 2007: impacts, adaptation and vulnerability. Contribution of Working Group II to the Fourth Assessment Report of the Intergovernmental Panel on Climate Change. Cambridge University Press, Cambridge, UK. Available online at: http://pubs.gi ss.nasa.gov/abstracts/2007/Easterling etal.html.

Ellis, F. 2000. Rural livelihoods and diversity in developing countries. Oxford University Press, Oxford, UK.

Ellis, F., and H. A. Freeman. 2004. Rural livelihoods and poverty reduction strategies in four African countries. Journal of Development Studies 40(4):1-30.

Ericksen, P. J. 2008. Conceptualizing food systems for global environmental change research. Global Environmental Change 18(1):234-245.

Fischer, G., M. Shah, F. N. Tubiello, and H. van Velthuizen. 2005. Socio-economic and climate change impacts on agriculture: an integrated assessment, 1990-2080. Philosophical Transactions of the Royal Society B: Biological Sciences 360:2067-2083.

Fischer, G., M. Shah, and H. van Velthuizen. 2002. Climate change and agricultural vulnerability. International Institute for Applied Systems Analysis, Vienna, Austria. Available online at: $\underline{w w}$ w.iiasa.ac.at/Research/LUC/JB-Report.pdf.

Folke, C. 2006. Resilience: the emergence of a perspective for social-ecological systems analyses. 
Global Environmental Change 16(3):253-267.

Food and Agriculture Organization. 1996. Rome declaration on world food security and World Food Summit Plan of Action. World Food Summit 13-17 November 1996. Food and Agriculture Organization, Rome, Italy.

Ford, J. D., B. Smit, and J. Wandel. 2006. Vulnerability to climate change in the Arctic: a case study from Arctic Bay, Canada. Global Environmental Change 16(2):145-160.

Fraser, E. D. G. 2003. Social vulnerability and ecological fragility: building bridges between social and natural sciences using the Irish potato famine as a case study. Conservation Ecology 7(2): 9. [online] URL: http://www.consecol.org/vol7/iss2/art9/

Fraser, E. D. G. 2006. Food system vulnerability: using past famines to help understand how food systems may adapt to climate change. Ecological Complexity 3(4):328-335.

Fraser, E. D. G., W. Mabee, and F. Figge. 2005. A framework for assessing the vulnerability of food systems to future shocks. Futures 37:465-479.

Füssel, H.-M., and R. T. J. Klein. 2006. Climate change vulnerability assessments: an evolution of conceptual thinking. Climatic Change $\mathbf{7 5}$ (3):301-329.

Global Environmental Change and Food Systems. 2005. Science plan and implementation strategy. Earth System Science Partnership (IGBP, IHDP, WCRP, DIVERSITAS) Report Number 2. Wallingford, UK. Available online at: http://www. gecafs.org/publications/index.html.

Global Environmental Change and Human Security. 1999. Global environmental change and human security science plan. International Human Dimensions Programme, Bonn, Germany. Available online at: www.ihdp.uni-bonn.de/html/publications/ reports/report11/gehssp.htm.

Gritti, E. S., B. Smith, and M. T. Sykes. 2006. Vulnerability of Mediterranean basin ecosystems to climate change and invasion by exotic plant species. Journal of Biogeography 33:145-157.

Gunderson, L. H. 2003. Adaptive dancing: interactions between social resilience and ecological crises. Pages 33-51 in F. Berkes, J. Colding, and C. Folke, editors. Navigating socialecological systems: building resilience for complexity and change. Cambridge University Press, Cambridge, UK.

Hendrickson, M. K., and W. D. Heffernan. 2002. Opening spaces through relocalization: locating potential resistance in the weaknesses of the global food system. Sociologia Ruralis 42(4):347-369.

Holling, C. S. 1986. The resilience of terrestrial ecosystems: local surprise and global change. Pages 292-317 in W. C. Clark and R. E. Munn, editors. Sustainable development of the biosphere. Cambridge University Press, Cambridge, UK.

Holling, C. S. 2001. Understanding the complexity of economic, ecological, and social systems. Ecosystems 4(5):390-405.

Ingram, J., and M. Brklacich. 2002. Global Environmental Change and Food SystemsGECAFS: a new interdisciplinary research project. die Erde 113(4):427-435.

Ison, R. L., P. T. Maiteny, and S. Carr. 1997. Systems methodologies for sustainable natural resources research and development. Agricultural Systems 55(2):257-272.

Leichenko, R. M., and K. L. O'Brien. 2002. The dynamics of rural vulnerability to global change: the case of southern Africa. Mitigation and Adaptation Strategies for Global Change 7(1):1-18.

Maxwell, S. 2001. The evolution of thinking about food security. Pages 13-31 in S. Devereaux and S. Maxwell, editors. Food security in sub-Saharan Africa. ITDG Publishing, London, UK.

McCarthy, J. J., O. F. Canziani, N. A. Leary, D. J. Dokken, and K. S. White, editors. 2001. Climate change 2001: impacts, adaptation and vulnerability. Contribution of Working Group II to the Third Assessment Report of the Intergovernmental Panel on Climate Change. Cambridge University Press, Cambridge, UK. Available online at: http://www.ip cc.ch/ipccreports/tar/wg2/index.htm.

McMichael, P. 2000. The power of food. Agriculture and Human Values 17(1):21-33.

McMichael, P. 2007. Feeding the world: agriculture, development and ecology. in L. Panitch 
and C. Leys, editors. Socialist register 2007: coming to terms with nature. Merlin Press, London, UK.

Millennium Ecosystem Assessment. 2003. Ecosystems and human well-being: a framework for assessment. Island Press, Washington, D.C., USA. Available online at: http://www.millenniumassessment. org/en/Framework.aspx.

Millennium Ecosystem Assessment. 2005. Ecosystems and human well-being: our human planet (summary for decision makers). Island Press, Washington, D.C., USA.

Misselhorn, A. A. 2005. What drives food insecurity in southern Africa? a meta-analysis of household economy studies. Global Environmental Change 15(1):33-43.

Nelson, D. R., W. N. Adger, and K. Brown. 2007. Adaptation to environmental change: contributions of a resilience framework. Annual Review of Environment and Resources 32:395-419.

O'Brien, K. 2006. Are we missing the point? Global environmental change as an issue of human security. Global Environmental Change 16(1):1-3.

O'Brien, K., S. Eriksen, A. Schjolden, and L. Nygaard. 2004a. What's in a word? Conflicting interpretations of vulnerability in climate change research. CICERO Working Paper 2004:04. Center for International Climate and Environmental Research, Oslo, Norway. Available online at: $\mathrm{ww}$ w.cicero.uio.no/media/2682.pdf.

O'Brien, K., R. Leichenko, U. Kelkar, H. Venema, G. Aandahl, H. Tompkins, A. Javed, S. Bhadwal, S. Barg, L. Nygaard, and J. West. 2004b. Mapping vulnerability to multiple stressors: climate change and globalization in India. Global Environmental Change 14(4):303-313.

Petschel-Held, G., A. Block, M. Cassel-Gintz, J. Kropp, M. K. B. Lüdeke, O. Moldenhauer, F. Reusswig, and H. J. Schellnhuber. 1999. Syndromes of global change: a qualitative modelling approach to assist global environmental management. Environmental Modeling and Assessment 4(4):295-314.

Reilly, J. M., and D. Schimmelpfennig. 1999. Agricultural impact assessment, vulnerability, and the scope for adaptation. Climatic Change $\mathbf{4 3}$ (4):745-788.
Schroter, D., W. Cramer, R. Leemans, I. C. Prentice, M. B.Araujo, N. W.Arnell, A. Bondeau, H. Bugmann, T. R. Carter, C. A. Gracia, A. C. de la Vega-Leinert, M. Erhard, F. Ewert, M. Glendining, J. I. Jouse, S. Kankaanpaa, R. T. J. Klein, S. Lavorel, M. Lindner, M. J. Metzger, J. Meyer, T. D. Mitchell, I. Reginster, M. Rounsevell, S. Sabate, S. Sitch, B. Smith, J. Smith, P. Smith, M. T. Sykes, K. Thonicke, W. Thuiller, G. Tuck, S. Zaehle, and B. Zierl. 2005. Ecosystem service supply and vulnerability to global change in Europe. Science 310:1333-1337.

Sen, A. 1981. Poverty and famines: an essay on entitlement and deprivation. Clarendon, Oxford, UK.

Shah, M., A. Xepapadeas, R. E. M. EntsuaMensah, G. Fischer, A. Haslberger, F. Jensen, M. M. Q. Mirza, E. Sartzetakis, and H. Simons. 2005. Food and cultivated ecosystems. Pages 173-212 in Millennium Ecosystem Assessment. Ecosystems and human well-being: policy responses. Island Press, Washington, D.C., USA. Available online at: http://www.millenniumassessment. org/en/Responses.aspx.

Stamoulis, K., and A. Zezza. 2003. A conceptual framework for national agricutural, rural development, and food security strategies and policies. ESA Working Paper Number 03-17. Food and Agriculture Organization, Rome, Italy. Available online at: http://www.fao.org/docrep/007/ ae050e/ae050e00.htm.

Steffen, W., A. Sanderson, P. D. Tyson, J. Jäger, P. A. Matson, B. Moore III, F. Oldfield, K. Richardson, H. J. Schellnhuber, B. L. Turner II, and R. J. Wasson. 2004. Global change and the earth system: a planet under pressure. SpringerVerlag, Berlin, Germany.

Stephen, L., and T. E. Downing. 2001. Getting the scale right: a comparison of analytical methods for vulnerability assessment and household-level targeting. Disasters 25(2):113-135.

Sundkvist, A., R. Milestad, and A. Jansson. 2005. On the importance of tightening feedback loops for sustainable development of food systems. Food Policy 30(2):224-239.

Turner II, B. L., R. E. Kasperson, P. A. Matson, J. J. McCarthy, R. W. Corell, L. Christensen, N. 
Eckley, J. X. Kasperson, A. Luers, M. L. Martello, C. Polsky, A. Pulsipher, and A. Schiller. 2003. A framework for vulnerability analysis in sustainability science. Proceedings of the National Academy of Science 100(14):8074-8079.

Vogel, C., and K. O'Brien. 2004. Vulnerability and global environmental change: rhetoric and reality. Aviso 13. [online] URL: http://www.gechs.org/avis o/13/.

von Braun, J. 2005. The world food situation: an overview. in CGIAR Annual General Meeting (Marrakech, 2005). International Food Policy Research Institute, Washington, D.C., USA. Available online at: http://www.ifpri.org/pubs/agm05/ jvbagm2005.asp.

Walker, B., S. Carpenter, J. Anderies, N. Abel, G. S. Cumming, M. Janssen, L. Lebel, J. Norberg, G. D. Peterson, and R. Pritchard. 2002. Resilience management in social-ecological systems: a working hypothesis for a participatory approach. Conservation Ecology 6(1): 14. [online] URL: http ://www.consecol.org/vol6/iss1/art14/.

Wood, S., S. Ehui, J. Alder, S. Benin, K. G. Cassman, H. D. Cooper, T. Johns, J. Gaskell, R. Grainger, S. Kadungure, J. Otte, A. Rola, R. Watson, U. Wijkstrom, and C. Devendra. 2005. Food ecosystem services. Pages 209-241 in Millennium Ecosystem Assessment. Ecosystems and human well-being: current state and trends. Island Press, Washington, D.C., USA. Available online at: http://www.millenniumassessment.org/en/ Condition.aspx.

Young, O. R., F. Berkhout, G. C. Gallopin, M. A. Janssen, E. Ostrom, and S. van der Leeuw. 2006. The globalization of socio-ecological systems: an agenda for scientific research. Global Environmental Change 16(3):304-316.

Ziervogel, G., A. Nyong, B. Osman, C. Conde, S. Cortés, and T. Downing. 2006. Climate variability and change: implications for household food security. AIACC Working Paper Number 20. Assessments of Impacts and Adaptations to Climate Change, Washington, D.C., USA. Available online at: www.aiaccproject.org/working papers/Working\% 20Papers/AIACC WP 20 Ziervogel.pdf. 
APPENDIX 1. What is included in a food system? Source: Ericksen (2008).

Food systems are often described as comprising four sets of activities: those involved in food production, processing and packaging, distribution and retail, and consumption. All encompass social, economic, political, and environmental processes and dimensions. To analyze the interactions between global environmental change and food systems, as well as the tradeoffs among food security and environmental goals, a food system can be more broadly conceived as including the determinants (or drivers) and outcomes of these activities. The determinants comprise the interactions between and within biogeophysical and human environments that determine how food system activities are performed. These activities lead to a number of outcomes, some of which contribute to food security and others that relate to the environment and other societal concerns. These outcomes are also affected directly by the determinants.

Food security is the principal policy objective of a food system. Food security outcomes are described in terms of three components and their subcomponents: food availability, i.e., production, distribution, and exchange; food access, i.e., affordability, allocation, and preference; and food use, i.e., nutritional and social values and safety. Although the food system activities have a large influence on food security outcomes, these outcomes are also determined directly by socio-political and environmental drivers. These outcomes vary by historical, political, and social context.

To capture these concepts holistically and to allow the analysis of impacts of global environmental change, adaptations, and feedbacks, a food system must include:

- $\quad$ interactions between and within biogeophysical and human environments that determine food system activities;

- the food system activities themselves;

- the outcomes of the activities, i.e., contributions to food security, environmental security, and other securities; and

- other determinants of food security, stemming in part from the interactions, rather than food system activities directly. 